\title{
LACTIC ACID BACTERIA FROM CINCALUK AND THE ACTIVITY AGAINST Vibrio alginolyticus AND Aeromonas hydrophila
}

\author{
Nursyirwani, Valentina Dian BP, Irwan Effendi* \\ ${ }^{1}$ Faculty of Fishery and Marine Sciences, University of Riau, Indonesia. \\ *helpingirwan@gmail.com
}

\begin{abstract}
Lactic acid bacteria (LAB) has been applied as probiotic mainly to prevent pathogens. This group of bacteria can be found in marine fish products including fermented, shrimp product, cincaluk. The objective of this research was to isolate $\mathrm{LAB}$ from cincaluk, and examined the activity against pathogen V. alginolyticus and A. hydrophila. The research was conducted on March-Juny, total of 12 isolates were obtained from cincaluk survey method. The result of research showed that all isolates round, creamy white, smooth-edged, raised surface, and the size is 1.0 to $3.0 \mathrm{~mm}$. The physiological and biochemical test showed that get all isolates had a Gram-positive, catalase positive and are indole negative, 10 isolates were motile, as many as five isolates have citric positive, 10 isolates is Methyl Red (+), all isolates ferment sucrose and lactose, while only 9 isolates ferment glucose, and as much as 6 isolates that produce sulfide. All isolates were found to have inhibitory effects against bacteria V. alginolyticus and A. hydrophila. The highest antimicrobial activity is indicated by B isolates with an average diameter of $12.3 \mathrm{~mm}$ and inhibition zone antivibrio activity of 6.3 units. Isolates B with an average diameter of inhibition zone of $9.7 \mathrm{~mm}$ and 3.7 units antiaeromonas activity.
\end{abstract}

Keywords: Isolation, Lactic Acid Bacteria, Cincaluk, V. alginolyticus, A. hydrophila

\section{PENDAHULUAN}

Usaha budidaya perikanan laut dan air tawar semakin berkembang sejalan dengan tingginya konsumsi ikan sebagai salah satu sumber protein hewani. Namun, sering dijumpai masalah seperti serangan penyakit yang ditimbulkan bakteri atau virus dan lambatnya pertumbuhan ikan. Berbagai usaha telah dilakukan untuk mencegah terjadinya serangan penyakit seperti dengan penggunaan antibiotik, pemberian imunostimulan, pemberian pakan berprotein tinggi dan pemberian vitamin untuk meningkatkan pertumbuhan ikan dan ketahanannya terhadap berbagai serangan penyakit. Namun, penggunaan antibiotik secara terus menerus juga akan menimbulkan dampak negatif terhadap ikan dan juga perairan budidaya. Akumulasi residu antibiotik pada daging ikan dapat membahayakan kesehatan konsumen dan penggunaan antibiotik secara kontiniu juga dapat menimbulkan mikroba yang resisten dan pencemaran di lingkungan perairan. Oleh karena itu, salah satu alternatif untuk mengatasi masalah tersebut adalah dengan pemberian probiotik.

Probiotik merupakan salah satu dari kelompok bakteri asam laktat. Probiotik telah banyak diaplikasikan pada budidaya perikanan dan memberi efek positif terhadap kesehatan, dapat menekan pertumbuhan bakteri patogen dan meningkatkan pertumbuhan ikan.

Bakteri asam laktat adalah bakteri yang mampu menghasilkan asam laktat, hidrogen peroksida, antimikrob dan hasil metabolisme lain yang memberikan pengaruh positif bagi produktivitas (Indriati, 2010). Sifat yang terpenting dari BAL ini adalah mempunyai kemampuan untuk merombak senyawa kompleks menjadi senyawa yang lebih sederhana sehingga dihasilkan asam laktat. BAL juga dapat menghasilkan senyawa yang bersifat antibakteri (Ruzana, 2011).

Penelitian bertujuan untuk mengisolasi bakteri asam laktat dari cincaluk yang dapat menekan pertumbuhan bakteri patogen, serta sebagai referensi dan data bagi pihak-pihak terkait.

\section{METODOLOGI PENELITIAN}

Penelitian ini telah dilaksanakan pada bulan Maret sampai Juni 2016. Isolasi dan identifikasi BAL dilakukan di Laboratorium Mikrobiologi Laut Jurusan Ilmu Kelautan 
Fakultas Perikanan dan Ilmu Kelautan Universitas Riau.

Metode yang digunakan dalam penelitian adalah metode survei, dimana produk makanan yaitu cincaluk segar dijadikan objek pengamatan dalam isolasi bakteri dan hasil isolasi bakteri diuji aktivitasnya terhadap bakteri patogen $V$. alginolitycus dan $A$. hydrophila.

Pertama dilakukan pengambilan sampel, penanganan sampel dengan cara mengisolasi, meremajakan dan memperbanyak isolat $\mathrm{BAL}$ dari sampel cincaluk, setelah itu dilakukan identifikasi BAL berdasarkan pengamatan morfologi koloni, uji sifat fisiologis dan uji biokimia. Uji sifat fidiologi dan biokimia yang dilakukan adalah uji pewarnaan Gram, uji katalase, uji motilitas, uji indol, uji citrat, uji Methyl Red, uji penggunaan gula dan uji sulfida. Selanjutnya, dilakukan uji antagonis terhadap bakteri $V$. alginolyticus dan $A$. hydrophila. Tujuan dilakukan uji ini adalah untuk mengetahui apakah isolat BAL yang diisolasi dari cincaluk tersebut bisa menekan pertumbuhan bakteri patogen seperti bakteri $V$. alginolyticus dan A. hydrophila.

Data yang diperoleh dari hasil isolasi dan identifikasi isolat BAL dan uji aktivitasnya terhadap bakteri patogen disajikan dalam bentuk tabel dan gambar. Selanjutnya data dianalisis secara deskriptif, didukung dengan studi literatur dan hasil-hasil penelitian terdahulu.

\section{HASIL DAN PEMBAHASAN}

Isolat Bakteri Asam Laktat. Hasil isolasi bakteri dari cincaluk pada media agar MRS setelah dilakukan pemurnian sebanyak 4 kali ditemukan sebanyak 12 isolat kandidat bakteri asam laktat dengan ukuran, warna, bentuk yang hampir sama dari setiap bakteri. Penambahan 1 gr $\mathrm{CaCO} 3$ kedalam media tumbuh bakteri bertujuan dalam seleksi tahap awal pada isolasi dan pemurnian BAL karena $\mathrm{CaCO} 3$ (Kalsium karbonat) yang bersifat basa memiliki kemampuan untuk menetralkan produksi asam yang dihasilkan oleh BAL, sehingga terbentuk zona jernih di sekitar koloni BAL akibat penetralan oleh $\mathrm{CaCO} 3$ terhadap asam yang dihasilkan oleh BAL (Gambar 1).

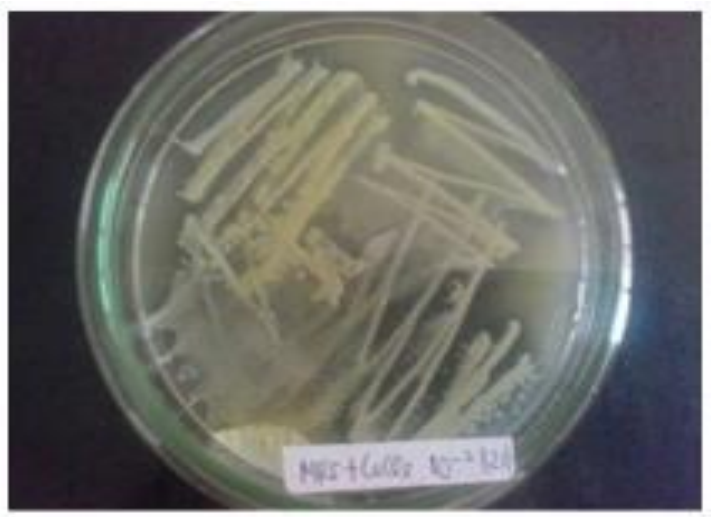

Gambar 1. Hasil positif pada media MRS Agar $+\mathrm{CaCO} 3$

Pada Gambar 1 dapat dilihat adanya zona jernih di sekitar koloni bakteri, sehingga diduga isolat-isolat tersebut termasuk kedalam kelompok BAL. Bakteri tersebut tumbuh pada $\mathrm{pH}$ 5-7. Bakteri yang tumbuh pada $\mathrm{pH}$ 3-8 merupakan salah satu ciri bakteri dari kelompok BAL yang sering dimanfaatkan sebagai probiotik. Untuk memastikan apakah isolat-isolat bakteri tersebut termasuk BAL, maka dilakukan identifikasi secara morfologi, sifat fisiologi dan biokimia sel.

Proses isolasi ini telah berhasil dilakukan oleh penelitian sebelumnya yang memperoleh isolat dari produk perikanan lainnya. Dwi et al (2012) berhasil mengisolasi isolat dari fermentasi kasava pada pembuatan growol sebanyak 230 isolat dari genus Lactobacillus. Kivanc et al (2011) berhasil mengisolasi 45 BAL dari 10 jenis boza (makanan di Turkey).

\section{Morfologi Koloni BAL. Hasil} pengamatan morfologi koloni bakteri menunjukkan hampir tidak ada perbedaan antara ke-12 isolat BAL tersebut. Berikut ini merupakan hasil dari pewarnaan Gram dan pengamatan morfologi dari keduabelas isolat bakteri (Tabel 1).

Berdasarkan Tabel 1 (sumber data primer) dapat dilihat bahwa koloni isolat BAL dari cincaluk dapat tumbuh dengan baik pada medium MRS Agar, pada umumnya berbentuk bundar dengan diameter 1,0 - 3,0 $\mathrm{mm}$, dan berwarna putih susu. Semua isolat memiliki pinggiran licin dan permukaan yang timbul. Hasilnya bersifat Gram positif serta katalase positif.

Tabel 1.Morfologi Koloni dan Uji Biokimia. 


\begin{tabular}{|c|c|c|c|c|c|c|c|}
\hline No & Kode Isolat & $\begin{array}{c}\text { Mledia } \\
\text { Tumbuh }\end{array}$ & $\begin{array}{l}\text { Diantr } \\
(\mathrm{mm})\end{array}$ & Bentuk & Warna & $\begin{array}{l}\mathrm{Uji} \\
\text { Gram }\end{array}$ & $\begin{array}{c}\text { Uji } \\
\text { Katalase }\end{array}$ \\
\hline 1 & Iso $\mathrm{A}$ & MRS Agar & 3,0 & Bundar & Putih susu & $(+)$ & $(+)$ \\
\hline 2 & Iso B & MRS Agar & 3,0 & Bundar. & Putih susu & $(+)$ & $(+)$ \\
\hline 3 & Iso C & MRS Agar & 2,0 & Bundar & Putih susu & $(+)$ & $(+)$ \\
\hline 4 & Iso D & MRS Agar & 2,0 & Bundar & Putih susu & $(+)$ & $(+)$ \\
\hline 5 & Iso E & MRS Agar & 1,0 & Bundar. & Putih susu & $(+)$ & $(+)$ \\
\hline 6 & Iso $\mathrm{F}$ & MRS Agar & 3,0 & Bundar & Putih susu & $(+)$ & $(+)$ \\
\hline 7 & Iso G & MRS Agar & 1,0 & Bundar. & Putih susu & $(+)$ & $(+)$ \\
\hline 8 & Iso $\mathrm{H}$ & MRS Agar & 2,0 & Bundar. & Putih susu & $(+)$ & $(+)$ \\
\hline 9 & Iso I & MRS Agar & 1,0 & Bundar. & Putih susu & $(+)$ & $(+)$ \\
\hline 10 & Iso J & MRS Agar & 2,0 & Bundar. & Putih susu & $(+)$ & $(+)$ \\
\hline 11 & Iso $\mathrm{K}$ & MRS Agar & 1.0 & Bundar & Putih susu & $(+)$ & $(+)$ \\
\hline 12 & Iso L & MRS Agar & 2,0 & Bundar & Putih susu & $(+)$ & $(+)$ \\
\hline
\end{tabular}

Hal tersebut hampir sama dengan yang dilakukan pada penelitian yang sebelumnya yang dilakukan oleh (Ilmiah et al, 2012) menjelaskan penampilan koloni isolat kandidat probiotik memiliki variasi warna koloni terdiri dari krem, putih, putih susu, putih transparan, putih kekuningan dan kuning. Ukuran dan bentuk koloninya juga bermacam-macam ada yang bulat besar dan bulat kecil.

Hasil pengamatan terhadap karakteristik koloni bakteri menunjukkan adanya beberapa perbedaan antara ke-12 isolat BAL tersebut. Hasil penelitian menunjukkan hampir semua isolat bersifat motil, indol negatif, sitrat (+) dan (-) uji gula (+) menghasilkan glukosa, laktosa dan sukrosa, dan menghasilkan sulfid $(+)$ dan tidak menghasilkan sulfid (-). Untuk lebih jelasnya dapat dilihat pada Tabel 2 .

Tabel 2. Uji Fisiologi dan Biokimia.

\begin{tabular}{|c|c|c|c|c|c|c|c|c|}
\hline $\begin{array}{l}\text { Kode } \\
\text { Isolat }\end{array}$ & Motilitas & Indol & Sitrat & $\begin{array}{l}\text { Methyl- } \\
\text { Red }\end{array}$ & Glukosa & Laktosa & Sukrosa & Sulfida \\
\hline Iso A & $(+)$ & $(-)$ & $(-)$ & $(-)$ & $(\sqrt{ })$ & $(\sqrt{ })$ & $(\sqrt{ })$ & $(+)$ \\
\hline Iso B & $(+)$ & $(-)$ & $(-)$ & $(+)$ & $(\sqrt{ })$ & $(\sqrt{ })$ & $(\sqrt{ })$ & $(+)$ \\
\hline Ise C & $(-)$ & $(-)$ & $(-)$ & $(+)$ & $(-)$ & $(\sqrt{ })$ & $(\sqrt{ })$ & $(-)$ \\
\hline Isso D & $(+)$ & $(-)$ & $(-)$ & $(+)$ & $(\sqrt{ })$ & $(\sqrt{ })$ & $(\sqrt{ })$ & $(-)$ \\
\hline $\mathrm{Is} g \mathrm{E}$ & $(+)$ & $(-)$ & $(+)$ & $(-)$ & $(\sqrt{ })$ & $(\sqrt{ })$ & $(\sqrt{ })$ & $(+)$ \\
\hline $\mathrm{Is} \rho \mathrm{F}$ & $(+)$ & $(-)$ & $(-)$ & $(+)$ & (v) & $(\sqrt{ })$ & $(\sqrt{ })$ & $(+)$ \\
\hline Iso $\mathrm{G}$ & $(+)$ & $(-)$ & $(-)$ & $(+)$ & $(\sqrt{ })$ & $(\sqrt{ })$ & $(\sqrt{ })$ & $(-)$ \\
\hline Iso $\mathrm{H}$ & $(+)$ & $(-)$ & $(+)$ & $(+)$ & $(-)$ & $(\sqrt{ })$ & $(\sqrt{ })$ & $(+)$ \\
\hline Iso I & $(+)$ & $(-)$ & $(-)$ & $(+)$ & (v) & $(\sqrt{ })$ & $(\sqrt{ })$ & $(-)$ \\
\hline Iso J & $(-)$ & $(-)$ & $(+)$ & $(+)$ & (v) & $(\sqrt{ })$ & $(\sqrt{ })$ & $(-)$ \\
\hline Iso K & $(+)$ & $(-)$ & $(+)$ & $(+)$ & $(\sqrt{ })$ & $(\sqrt{ })$ & $(\sqrt{ })$ & $(+)$ \\
\hline Isso L & $(+)$ & $(-)$ & $(+)$ & $(+)$ & $(-)$ & $(\sqrt{ })$ & $(\sqrt{ })$ & $(-)$ \\
\hline
\end{tabular}

Pada Tabel 2 didapatkan hasil dari pengamatan uji fisiologi dan uji biokimia dari BAL yang diisolasi dari cincaluk. Sebanyak 10 isolat BAL bersifat motil (+) dan 2 isolat inmotil (-), semua isolat BAL memiliki indol (), 5 isolat BAL memiliki sitrat (+) dan 7 isolat memiliki sitrat (-), 10 isolat BAL dengan Methyl Red (+) dan 2 isolat memiliki Methyl
Red (-), semua isolat BAL memfermentasi sukrosa dan laktosa dan 9 isolat memfermentasi glukosa, 6 isolat BAL menghasilkan sulfida dan 6 isolat tidak menghasilkan sulfida.

Sifat fisiologi isolat bakteri yang diuji meliputi sifat-sifat sebagai berikut: reaksi Gram dengan pewarnaan atau dilakukan dengan uji kalium hidroksida (KOH 3\%). Isolat bakteri bersifat Gram negatif (-) jika berwarna merah atau terbentuk benang lendir bakteri (kira-kira 5-20 mm panjangnya). Gram positif (+) jika berwarna ungu atau tidak terbentuk benang lendir, kemampuan isolat memproduksi katalase, kemampuan isolat menghidrolisis pati, kemampuan isolat dalam penggunaan gula, kemampuan isolat dalam penggunaan sitrat, kemampuan isolat dalam melakukan oksidasi, kemampuan motilitas isolat (Cappuccino dan Sherman, 1996).

Aktivitas dan Bakteri Patogen. Hasil uji aktivitas BAL terhadap bakteri patogen dilihat dari zona bening yang terbentuk di sekitar cakram yang diletakkan pada permukaan media yang berisi bakteri patogen. Zona bening diukur dengan menggunakan jangka sorong dan dirata-ratakan. Hasil pengukuran rata-rata aktivitas zona bening terhadap bakteri $V$. alginolyticus dapat dilihat pada Tabel 3.

Tabel 3. Daya Hambat BAL Terhadap Bakteri V. alginolyticus

\begin{tabular}{|c|c|c|c|c|}
\hline \multirow[t]{2}{*}{ Kode Iso } & \multicolumn{3}{|c|}{ Pengulangan (mm) } & \multirow[t]{2}{*}{ Rata-rata (mm) } \\
\hline & 1 & 2 & 3 & \\
\hline Iso A & 6 & 5 & 4 & $5 \pm 1$ \\
\hline Iso B & 5 & 7 & 7 & $6,3 \pm 1,2$ \\
\hline Iso $\mathrm{C}$ & 5 & 4 & 7 & $5,3 \pm 1,5$ \\
\hline Iso D & 5 & 6 & 5 & $5,3 \pm 0,6$ \\
\hline Isoo E & 4 & 5 & 6 & $5 \pm 1$ \\
\hline Iso $\mathrm{F}$ & 4 & 6 & 6 & $5,3 \pm 1,2$ \\
\hline Iso G & 6 & 5 & 4 & $5 \pm 1$ \\
\hline Iso $\mathrm{H}$ & 6 & 5 & 2 & $4,3 \pm 2,1$ \\
\hline Iso I & 3 & 5 & 5 & $4,3 \pm 1,2$ \\
\hline Iso $\mathrm{J}$ & 4 & 4 & 7 & $5 \pm 1,7$ \\
\hline Isol $\mathrm{K}$ & 4 & 3 & 4 & $3,6 \pm 0,6$ \\
\hline Isog L & 5 & 3 & 4 & $4 \pm 1$ \\
\hline Kontrol (+) & 10 & 10 & 10 & $10 \pm 0$ \\
\hline Kontrol (-) & 0 & 0 & 0 & 0 \\
\hline
\end{tabular}

Berdasarkan Tabel 3 dapat dilihat nilai rata-rata daya hambat isolat yang diisolasi pada medium MRS Agar terhadap bakteri $V$. alginolyticus berkisar antara 3,6 $\mathrm{mm}$ sampai $6,3 \mathrm{~mm}$. Nilai daya hambat yang paling tertinggi ialah isolat $\mathrm{B}$ sebesar 6,3 $\mathrm{mm}$, dan nilai hambat yang terendah adalah isolat $\mathrm{K}$ sebesar $3,6 \mathrm{~mm}$, dimana nilai kontrol positif sebesar $10 \mathrm{~mm}$ dan nilai kontrol negatif $0 \mathrm{~mm}$. 
Setelah dilakukan pengamatan juga didapatkan hasil pengukuran rata-rata aktivitas zona bening terhadap bakteri $A$. hydrophila yang dapat dilihat pada Tabel 4 dibawah ini.

Tabel 4. Daya Hambat Terhadap Bakteri $A$. hydrophila

\begin{tabular}{|c|c|c|c|c|}
\hline \multirow[t]{2}{*}{ Kode Iso } & \multicolumn{3}{|c|}{ Pengulangan $(\mathrm{mm})$} & \multirow[t]{2}{*}{ Rata-rata (mm) } \\
\hline & 1 & 2 & 3 & \\
\hline Iso A & 1 & 3 & 3 & $2,3 \pm 1,6$ \\
\hline Iso B & 3 & 2 & 6 & $3,7 \pm 2,1$ \\
\hline Iso C & 5 & 0 & 4 & $3 \pm 2,6$ \\
\hline Ison D & 4 & 3 & 0 & $2,3 \pm 2,1$ \\
\hline Iso E & 1 & 4 & 0 & $1,7 \pm 2,1$ \\
\hline Ison $\mathrm{F}$ & 0 & 4 & 5 & $3 \pm 2,6$ \\
\hline Iso $\mathrm{G}$ & 3 & 3 & 0 & $2 \pm 1,7$ \\
\hline Iso $\mathrm{H}$ & 3 & 4 & 0 & $2,3 \pm 2,1$ \\
\hline Isol I & 0 & 4 & 2 & $2 \pm 2$ \\
\hline Iso J & 1 & 0 & 0 & $0,3 \pm 0,6$ \\
\hline Iso K & 1 & 0 & 0 & $0,3 \pm 0,6$ \\
\hline Iso L & 0 & 5 & 0 & $1,7 \pm 2,9$ \\
\hline Kontrol (+) & 7 & 5 & 6 & $6 \pm 1$ \\
\hline Kontrol (-) & 0 & 0 & 0 & 0 \\
\hline
\end{tabular}

Nilai rata-rata daya hambat isolat yang diisolasi pada medium MRS Agar terhadap bakteri $A$. hydrophila berkisar antara $0,3 \mathrm{~mm}$ sampai 3,7 $\mathrm{mm}$. Nilai daya hambat yang paling tertinggi ialah isolat B sebesar 3,7 mm dan nilai hambat yang terendah ialah isolat $\mathrm{J}$ dan isolat $\mathrm{K}$ sebesar $0,3 \mathrm{~mm}$, dimana nilai kontrol positif sebesar 6 $\mathrm{mm}$ dan nilai kontrol negatif $0 \mathrm{~mm}$.

Hasil yang diperoleh berupa terbentuknya zona hambat sudah cukup membuktikan bahwa isolat bakteri asam laktat yang diisolasi dari cincaluk mempunyai kemampuan untuk menekan pertumbuhan bakteri patogen ( $V$. algynoliticus dan $A$. hydrophila). Nilai hambat isolat BAL rata-rata diatas $6 \mathrm{~mm}$, ini disebabkan oleh ukuran kertas cakram yang digunakan sehingga ukuran luasan usapan bakteri pada saat uji mencapai $6 \mathrm{~mm}$. Namun, itu tidak menjadi alasan utama karena masih ada faktor lain yaitu aktivitas enzim yang dihasilkan oleh bakteri asam laktat.

Pada cincaluk, semua isolat yang diuji mampu menghambat pertumbuhan bakteri $V$. alginolyticus dan $A$. hydrophila yang tumbuh pada media MRS Agar. Isolat B mempunyai kemampuan yang lebih besar untuk menghambat dan membunuh bakteri $V$. alginolyticus dan bakteri A. hydrophila, dan bisa diduga Isolat $\mathrm{B}$ mampu menghasilkan bakteriosin yang lebih banyak dibandingkan isolat BAL lainnya. Munatin dan Khanifa (2012) mengatakan kemampuan bakteri asam laktat untuk menekan pertumbuhan bakteri patogen disebabkan karena kemampuannya untuk memproduksi senyawa antimikroba seperti asam laktat dan asam asetat, hidrogen peroksida yang cukup besar dan bakteriosin.

Isolat BAL yang diisolasi dari cincaluk menunjukkan memiliki aktivitas antibakteri terhadap bakteri patogen dan bisa berpotensi untuk dikembangkan sebagai salah satu alternatif sumber antibakteri sehingga dapat memberikan nilai tambah terhadap kegiatan budidaya ikan.

\section{KESIMPULAN DAN SARAN}

Berdasarkan hasil penelitian dapat disimpulkan bahwa Sebanyak 12 isolat BAL telah ditemukan dari cincaluk. Semua koloni isolat BAL yang tumbuh umumnya berbentuk bulat, berwarna putih susu, bersifat Gram (+), memiliki katalase (+), dan bersifat indol (-). Sebanyak 10 isolat bersifat motil (+), dan 2 isolat bersifat inmotil (-). Sebanyak 5 isolat memiliki sitrat (+) dan 7 isolat memiliki sitrat (-). Sebanyak 10 isolat memiliki Methyl Red (+), dan 2 isolat memiliki Methyl Red (-). Ke12 isolat memfermentasi sukrosa dan laktosa, sedangkan yang mengalami fermentasi glukosa hanya 9 isolat. Sebanyak 6 isolat yang menghasilkan $\mathrm{H} 2 \mathrm{~S}$ dan gas.

Semua isolat yang diuji memilki daya hambat terhadap bakteri $V$. alginolyticus dan $A$. hydrophila. Uji sensitivitas tertinggi ditunjukkan oleh isolat $\mathrm{B}$ dengan rata-rata diameter zona hambat $12,3 \mathrm{~mm}$ dan aktivitas antivibrio 6,3 unit. Isolat $\mathrm{B}$ dengan rata-rata diameter zona hambat $9,7 \mathrm{~mm}$ dan aktivitas antiaeromonas 3,7 unit. Daya hambat Isolat BAL yang ditemukan dari cincaluk terhadap bakteri patogen ( $V$. alginolyticus dan $A$. hydrophila) lebih kecil dari pada daya hambat kontrol positif (amoxilin). Diharapkan dari hasil penelitian ini bisa dilanjutkan untuk melakukan penelitian dengan uji biokimia lanjutan dan uji genetik untuk memperoleh genus dan spesies. Disarankan juga dilakukan uji antagonis terhadap bakteri lain seperti: Pseudomonas dan Strepttococcus agalactiae dan analisis metabolit sekunder yang dihasilkan oleh bakteri. 


\section{DAFTAR PUSTAKA}

1. Cappuccino, J.G., and N. Sherman. 1996. Microbiology a Laboratory Manual. The Benjamin Cummings, California.

2. Dwiastuti, E.A,. 2012. Pengaruh Penambahan Serbuk Bawang Putih (Allium sativum) dan Serbuk Cabai (Capsium Annuum L.) terhadap Karakteristik Cincalok. Pontianak: Jurusan Kimia, Fakultas MIPA, Universitas Tanjungpura, (Skripsi).

3. Ilmiah, Sukenda,Widanarni, E. Haris. 2012. Seleksi bakteri probiotik dari terumbu karang dan lingkungan budidaya ikan kerapu macan (Epinephelus fuscoguttatus).Jurnal Akuakultur Indonesia 11(2), Bogor.hal 109-117.

4. Indriati, N., Nandang Priyanto, dan Radestya, T. 2010. Penggunaan Dichloran Rose Bengal Chloramphenicol Agar (Drbc) Sebagai Media Tumbuh Kapang Pada Produk Perikanan. Jurnal Pascapanen dan Bioteknologi Kelautan dan Perikanan. Vol 5, no.2.

5. Kivanc, M., Meral Yilmaz, and Erdogan, C. 2011. Isolation and Identification of Lactid Acid Bacteria from Boza and their microbial activity Againts Several Reporter Strains. 35 (2001) 313324.

6. Munatin, A dan Khanifa. 2012, Uji potensi probiotik Lactobacillus plantarium secara in-vitro, Malang. ALCHEMY, Vol. 2.

7. Ruzana. 2011. Isolasi dan Identifikasi Bakteri Asam Laktat Penghasil Antibakteri dari Feses Bayi. [Tesis]. Universitas Brawijaya, Malang. 